\title{
Mysterious Side of COVID-19 Pandemic: Children
}

\section{COVID-19 Pandemisinin Gizemli Yanı: Çocuklar}

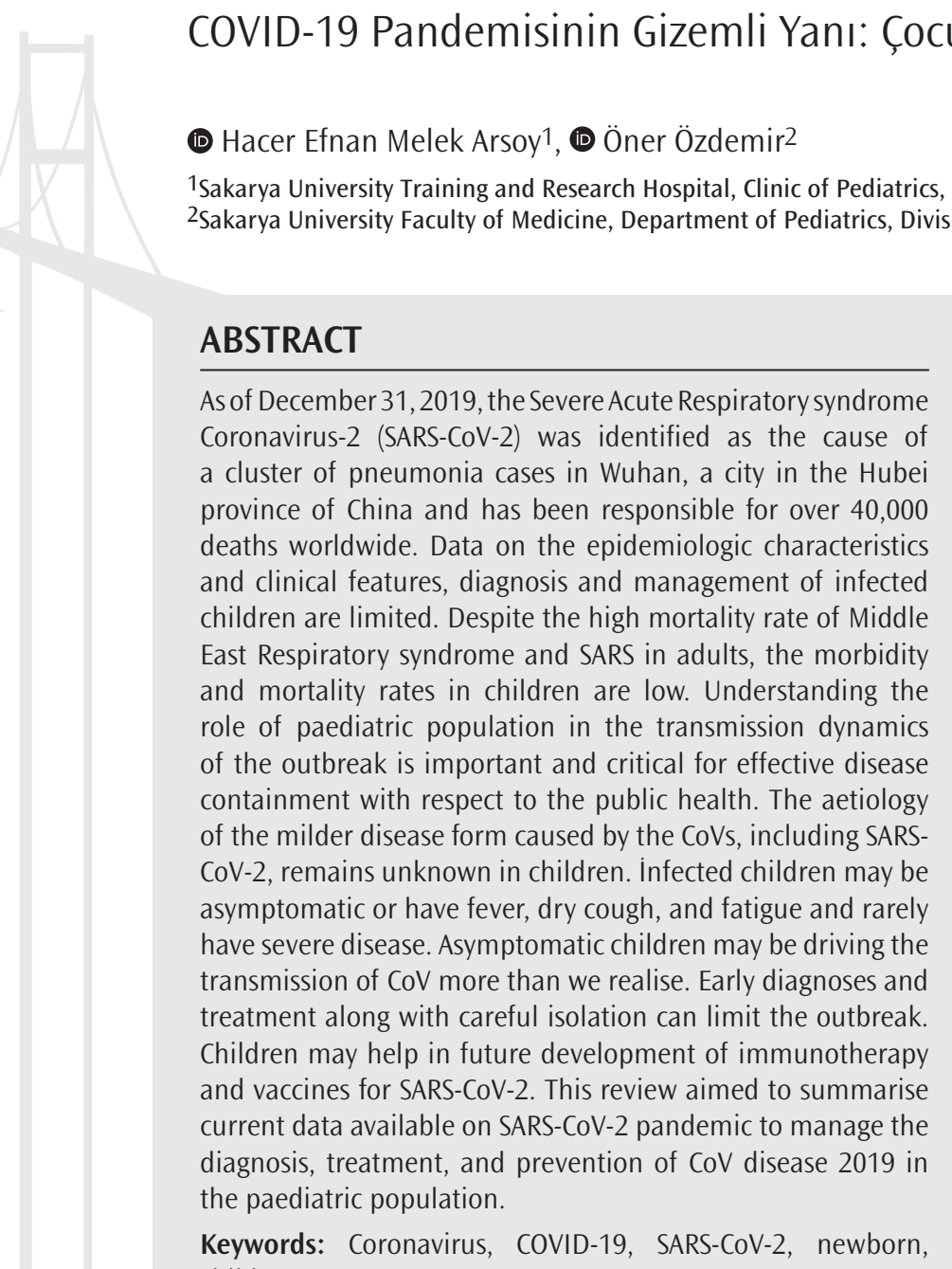

ÖZ

31 Aralık 2019'dan itibaren dünya çapında 40,000'den fazla ölümden sorumlu olan 2019'un yeni koronavirüsü [Șiddetli Akut Solunum sendromu - Koronavirüs-2 (SARS-CoV-2)], Çin'in Hubei eyaletindeki bir șehir olan Wuhan'da pnömoni olgularının nedeni olarak tanımlanmıștır. Enfekte çocukların epidemiyolojik özellikleri ve klinik özellikleri tanı, tedavisi ile ilgili veriler sınırlıdır. Orta Doğu Solunum sendromu ve SARS'da yetișkinlerde yüksek mortalite oranına rağmen, çocuklarda ölüm ve morbidite oranları azdır. Salgının bulașma dinamiklerinde pediyatrik popülasyonun rolünün anlașılması, halk sağlığı kontrolünün etkili olması için önemli ve kritiktir. Çocukların SARS-CoV-2 de dahil olmak üzere koronavirüslerin neden olduğu hastalıkları neden daha hafif atlattıkları bilinmemektedir. Enfekte çocukta semptom olmayabileceği gibi ateș, kuru öksürük ve yorgunluk olabilir ya da nadiren kritik seyredebilir. Asemptomatik çocuklar virüsün farkettiğimizden daha fazla yayılmasına neden olabilir. Erken teșhis ve tedavi ve dikkatli izolasyon salgını sınırlandırabilir. Çocuklar SARS-CoV-2 için immünoterapi ve aşıların gelecekteki gelişimine yardımcı olabilir. Bu derlemede pediyatrik popülasyonda COVID-19'un tanısı, tedavisi ve önlenmesine rehberlik etmek için SARS-CoV-2 pandemisi hakkındaki mevcut veriler özetlenmiștir.

Anahtar Kelimeler: Koronavirüs, COVID-19, SARS-CoV-2, yenidoğan, çocuk children

\section{Introduction}

On 31 December 2019, unknown pneumonia cases were reported in people associated with the Huanan Seafood Wholesale Market in Wuhan, Hubei Province, China. On January 7, 2020, the Chinese health authorities confirmed that this case community was associated with a new type of coronavirus (1). Later, this clinical picture was named Coronavirus disease 2019 (COVID-19), and its factor was reported as "Severe Acute Respiratory syndrome Coronavirus 2 (SARS-CoV-2)" (2).
COVID-19, which has been declared a pandemic with current data, continues to spread by increasing the number of infected cases and mortality day by day. SARS-CoV, an epidemic with viruses from the same family, appeared in 2002-2003, while 8,000 cases and 800 deaths occurred; Middle East Respiratory syndrome (MERS)-CoV appeared in 2012, causing 2,500 cases and 800 deaths (3). On March 11, 2020, the World Health Organization (WHO) classified the COVID-19 infection as a pandemic. As of March 31, 2020, more than 825,000 confirmed cases and more than 40,000 deaths (an approximate fatality rate of $4.8 \%$ ) have

Cite this article as/Atıf: Melek Arsoy HE, Özdemir Ö. Mysterious Side of COVID-19 Pandemic: Children. İstanbul Med J 2020; 21(4): 242-57. 
been reported. Comparison of the characteristics of SARS, MERS and COVID-19 diseases are shown in Table $1(3,4)$.

For now, the main source for the disease is patients infected with COVID-19. Contagion is known to be through droplets or contact from the respiratory tract, but there is no clear information about the fecaloral or vertical transition. One of the key differences of the coronavirus 2019 pandemic is that most of the information is generated by adult patient data. MERS-CoV infection, which is from the same family as COVID-19 disease factor, also affects children less and has less mortality if the affected patient does not have any underlying comorbid disease (5). As discussed in detail below, information about infected children and infants is limited and scattered.

The first pediatric case was reported on January 20 in Shenzen. On February 10, 398 confirmed cases of children were reported in China outside the Hubei region. Hubei region was excluded because children were screened less in there $(6,7)$. Numbers reported from Italy on 18 March were that $1.2 \%$ of 22,512 cases were children and it did not cause death in children (8). On March 16, the United States announced that $5 \%$ of 4,226 COVID-19 cases were children (9). In a report from China, only $2 \%$ of COVID-19 infections were in people under 20 (10). Similarly, only $6.3 \%$ of the nearly 8,000 infections in South Korea have been seen in those under the age of 20 (11). Like MERS-CoV, there may be different reasons why SARS-CoV-2 is rarely seen in children. As discussed below, children surviving with asymptomatic or mild symptoms may be due to low exposure to the virus, immature immune systems and a number of factors that are not yet identified. The more screening is done, the higher the rate may appear in children and adolescents.

This article is compiled in order to make earlier diagnosis of asymptomatic children which are considered as a hidden source rather than the patient in infectious and epidemic prevention studies and to review the innovations in treatment, with the differences in diagnosis, stimulant clinical findings and laboratory data.

\section{Etiopathogenesis}

Coronavirus was first isolated in the tissue culture of a patient with a cold in 1965. Culture durations are 4 days in human airway epithelial cells and 6 days in Vero E6/Huh - 7 cells. CoVs are single-chain, enveloped, ribonucleic acid (RNA) viruses that can be isolated from different animals in diameters of about 60 to $140 \mathrm{~nm}$ (12). SARS-CoV-2 has low resistance to external environment, it is easily deactivated at 56 ${ }^{\circ} \mathrm{C}$ in 30 minutes or with $60-80 \%$ ethanol and chlorinated disinfectants, chloroform (excluding chlorhexidine) and peracetic acid (13).

The Coronaviridae family is part of the Nidovirales team, consists of the Coronavirinae and Torovirinae subfamilies, causing various diseases in the respiratory, enteric, neurological and hepatic system by infecting mammals and birds (3). The virus family can be examined in 4 groups. Alpha and beta groups infect mostly mammals, gamma and delta mostly birds. The most known subgroup is the genus Alphacoronavirus, which causes classic cold symptoms in human. SARS-CoV and MERS-CoVise are in genus Beta-coronavirus. It is known that both

\begin{tabular}{|c|c|c|c|}
\hline Properties & SARS & MERS & COVID-19 \\
\hline The first reported patient & Guangdong, China November 2002 & $\begin{array}{l}\text { Zarga, Jordan } \\
\text { April } 2012 \\
\text { Saudi Arabia June } 2010\end{array}$ & $\begin{array}{l}\text { Wuhan, China } \\
\text { December } 2019\end{array}$ \\
\hline Virus & SARS-CoV & MERS-CoV & SARS-CoV-2 \\
\hline Animal host & $\begin{array}{l}\text { Bat (natural carrier) } \\
\text { Musk cat and raccoon } \\
\text { (intermediate host) }\end{array}$ & $\begin{array}{l}\text { Bat (natural carrier) } \\
\text { Single humped camel } \\
\text { (intermediate host) }\end{array}$ & $\begin{array}{l}\text { The bat (possible natural carrier) can } \\
\text { be the intermediate host in the seafood } \\
\text { market (pagolin?) }\end{array}$ \\
\hline Incubation period & 2-14 days & 2-13 days & 2-14 days \\
\hline $\begin{array}{l}\text { The period from the start of the disease } \\
\text { until the hospital application }\end{array}$ & 2-8 days & $0-16$ days & 0-9.1-12.5 (data incomplete) \\
\hline Adult & $93 \%$ & $98 \%$ & $90 \% ?$ \\
\hline Child & $5-7 \%$ & $2 \%$ & $2.5-10 \% ?$ \\
\hline Age range & 1-91 years & $1-94$ years & 36 hours-89 years \\
\hline Gender M/F & $43-57 \%$ & $64.5-35.5 \%$ & $56-44 \%$ \\
\hline Number of deaths & 774 & 862 & 41000 (31 March 2020) \\
\hline Mortality & $9.6 \%$ & $35-40 \%$ & 4.8\% (31 March 2020) \\
\hline Effects in pregnancy & $\begin{array}{l}3 / 12 \text { pregnancy death } \\
\text { No vertical transition }\end{array}$ & No vertical transition & $\begin{array}{l}\text { No vertical transition? } \\
\text { (In } 36 \text { hour newborn SARS-CoV-2 PCR +) }\end{array}$ \\
\hline
\end{tabular}


viruses tend to infect intrapulmonary epithelial cells instead of upper respiratory epithelial cells (14). SARS-CoV-2 virus, which has a cytopathic effect in cell culture and is in beta group, has been shown to have a 86.9\% nucleotide sequence similarity with bat-derived SARS-like CoV (bat-SL-CoVZC45, MG772933.1) in phylogenetic analysis. The SARSCoV-2 chain is $79 \%$ similar to SARS-CoV and 50\% similar to MERS-CoV (15). Its phylogenetically similar features shed light on the treatments developed.

\section{Differences in Sensitivity of Children and Adults to COVID-19}

There are some studies investigating why the disease is transmitted in children with a milder clinic picture. Due to the immature immune system in children, there are some data supporting the rarely occurrence or slight affect of some infections. For example; It has been shown that immature mice do not have poliovirus-induced paralysis due to maturational changes of the axonal transport system (16). Another thesis is that children have a more active natural immune response. Unlike adults, less exposure to air pollution and cigarette smoke, and other factors such as underlying diseases are thought to be the reason for the healthier airways of children. In addition, acute respiratory distress syndrome (ARDS) was associated with a much stronger immune response reaction in adults. One of the most remarkable reasons among these is that the distribution, maturation and functional differences of viral receptors vary depending on age. SARS-CoV, SARS-CoV-2 and human coronavirus NL63 use the SARS-CoV receptor, namely angiotensin converting enzyme-2 (ACE-2) as a cell receptor to enter the host cells in humans. As a result, these and similar effects can be cited as the reason why children are more resistant to COVID-19 infections (17).

Expression of ACE-2 in the lungs of mice has been found to be significantly reduced with increasing age. Although this is not consistent with children's low sensitivity to SARS-CoV-2, it has also been noted that ACE-2 functions as the protective mechanism of the lungs. It has been demonstrated in experimental mouse studies and pediatric patients that ACE-2 plays a protective role from severe lung damage caused by virus infections involving the respiratory tract. ACE-2 also protects against acute severe lung damage triggered by sepsis, respiratory syncytial virus (RSV), acid aspiration, SARS, and terminal bird flu H5N1 virus infection. In addition, administration of the recombinant ACE-2 protein has been shown to reduce the severity of lung damage caused by RSV. Even decrease in ACE-2 protein levels in the lungs of mice was detected during RSV infection (18).

In a different study, it was reported that the main reason for children to be less affected is that ACE-2 protein actually acts as a receptor for virus entry, but is related to the development and function of ACE-2 protein, such as low sensitivity, low binding ability or differences of ACE2 in children. Thus, the fact that ACE-2-induced intracellular response in alveolar epithelial cells in children lower than in adults is considered as the reason of that children are less affected by the disease (19).

ACE-2 is a surface molecule and is also expressed in the upper esophageal epithelial cells and in the absorptive parts of enterocytes in the ileum and colon, and mostly in AT-2 cells located in the lungs. This explains how COVID-19 affects the digestive system, like the lungs, as a potential pathway. The ACE-2 expression level in Asian populations is significantly higher than in European and American populations. ACE-2 expression in men's cells is higher than in women's. The high incidence of coronavirus in Asian men can explain the pneumonia rates (19).

In adults infected with the SARS-CoV-2 virus, there is a markable or progressive decrease in the number of peripheral absolute lymphocytes at an early stage. Both the CD4+ and CD8+ lymphocyte count decrease, and the neutrophil/lymphocyte ratio increases as SARS-CoV-2 consumes lymphocytes as an early and prominent sign (20). This proves that the virus used lymphocytes to reproduce and spread in the early stages. Adult cases become severe within 7-10 days from the onset of the disease. As a result of rapid virus replication, inflammatory cell infiltration, proinflammatory cytokines, and chemokine response increase, transition to ARDS, which is fatal lung injury occurs (20). The fact that the number of leukocytes and absolute lymphocytes is quite normal and there is no decrease in lymphocytes after the SARS-CoV-2 infection in children suggests that there is fewer immune dysfunction.

On the other hand, mild COVID-19 disease in children may be associated with trained immunity/active immunization. The creation of a trained immune system is a new immune model. Some designated vaccines, such as Bacillus Calmette Guerin (BCG), create immune memory by training natural immunity. In a study in mice, nonspecific protection against influenza virus has been demonstrated by stimulating trained immunity depending on BCG vaccine administration. Most of the children in China and Asia are regularly vaccinated according to the routine scheme, which also includes BCG. In the light of this information, it should be investigated in more detail in terms of educating the immune system with vaccination, which may be one of the reasons why children have less ARDS than adults (21).

\section{Infectiousness}

Although the incubation period of the virus is known as 5-6 days, it can be extended up to 14 days. Contagion begins 1-2 days before symptoms begin. The infection was initially seen among the adults, and then the elderly and children become infected by spreading around the family and creating a "cluster". SARS-CoV-2 is transmitted from human to human by droplet, contact and aerosol. Infection occurs when these droplets are inhaled or touched on the surfaces contaminated by the virus and then brought to the nose, mouth and eyes. Although it is known that it cannot travel more than 2 meters in the air and cannot remain suspended for a long time, it has been shown in an article that SARS-CoV-2 aerosols can remain active for at least 3 hours under experimental conditions (22). Therefore, attention should be paid to aerosol-forming conditions and processes to reduce spread in this way (Table 2) (23).

Vaginal birth is considered as a transmission route due to close mother-baby contact. Although it is thought that the possibility of transmission in vaginal birth is high, there is no evidence of this. SARS-CoV-2 was found to be negative in all babies born with cesarean from 9 symptomatic pregnant women with COVID-19. Amniotic fluid, cord blood samples from six patients, nasopharyngeal specimen from neonates and breast milk samples resulted negative for SARS-CoV-2 (24). In an article suggesting vertical transition and showing that newborns were affected, thrombocytopenia was observed along with 1/10 death 
Table 2. Aerosol-forming states and processes (95)

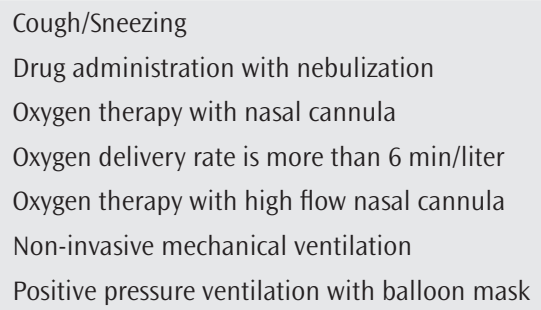

\author{
Endotracheal intubation \\ Separation of ventilator circuits \\ Open system tracheal aspiration \\ Tracheostomy \\ Bronchoscopy \\ Cardiopulmonary resuscitation
}

incidence, premature birth, fetal distress, respiratory failure, impaired liver function (25). In a letter-type article, it was claimed that a serumspecific IgM-type antibody specific to SARS-CoV-2 was detected in the serum of the newborn, suggesting a vertical transition (26).

The isolation of SARS-CoV-2 in stool and anal swab in mother and infant without gastrointestinal symptoms supports possible faecal-oral passage as a potential passageway. The subsequent positivity of fecal RNA from the positivity of pharyngeal RNA may suggest that the virus has been ingested and passed into the digestive system. Also, fecal RNA negativity occurs much later than pharyngeal RNA negativity. After pharyngeal samples become negative, sputum and stool tests can remain positive for up to 39 and 13 days, respectively. It may be related to the fact that the digestive system clears the virus much slower than the respiratory system (27-29). In the urine sample, RNA was detected in very few patients. Despite this, many studies have not shown virus spread in the urinary system $(27,28,30)$.

\section{Is There a Connection Between Transmission and Viral Load?}

Seventy six COVID-19 patients verified with reverse transcription polymerase chain reaction (RT-PCR) were evaluated at Nanchang University. The average viral load of severe cases was found to be 60 times higher on average than mild cases, suggesting that higher viral loads may be associated with serious clinical consequences. In $90 \%$ of mild cases, the RT-PCR tests became negative on the $10^{\text {th }}$ day after the onset of the disease, also demonstrating early viral clearance in mild cases. In all severe cases, RT-PCR test was positive on the $10^{\text {th }}$ day or later. Patients with severe COVID-19 disease picture appear to have a high viral load and a long virus release time. This finding suggests that the viral load of SARS-CoV-2 may be a useful marker to assess disease severity and prognosis (31).

\section{Clinical Findings}

It is known that the incubation period of SARS-CoV-2 is between 1 and 14 days (an average of 5.2 days) and symptoms of $97.5 \%$ of those symptomatic occur within 10.5 days (32). The latest diagnosis was made on day 42 from the onset of the disease (average 2 days, range: 0 to 42 days) (33).

In the series prepared with data of 2,143 children (median age 7), including 731 (34.1\%) laboratory-approved cases and 1,412 (65.9\%) suspected cases with COVID-19 infection, without gender difference, more than $90 \%$ of all patients have asymptomatic, mild or moderate clinical picture. The most common clinical symptoms in 171 confirmed patients were cough (48.5\%), pharyngeal erythema (46.2\%), fever
(41.5\%), diarrhea (8.8\%), fatigue (7.6\%), nasal flow (7.6\%) and vomiting (6.4\%). $32.2 \%$ of the patients had a high fever of $38{ }^{\circ} \mathrm{C}$. Tachycardia (42.1\%) and tachypnea (28.7\%) were common findings at admission (33). Another study on 6 children aged 1 to 7 years hospitalized with COVID-19 in Wuhan, all had fever $>39{ }^{\circ} \mathrm{C}$ and cough, four of them had viral pneumonia on imaging, and one patient was taken into intensive care. All children were recovered and discharged (34). In the study conducted out of the neonatal group, most of the patients' (8/10) fever recovered within 24 hours (35). One of the diagnosed patients had only diarrhea (36). 5.2\% of patients had dyspnea, central cyanosis, severe with less than $92 \%$ oxygen saturation level and $0.6 \%$ of them had respiratory failure, ARDS, shock, multiorgan failure (encephalopathy, heart failure, coagulation disorder and acute renal failure, etc). Only 4 children had oxygen saturation below 92\% (33). In the first case series article on children with COVID-19, it was additionally shown that the fever period was shorter and resolved rapidly in mild cases (28). Some patients with or without cough symptoms may have patchy infiltration in their pulmonary X-rays. In a 10-year-old asymptomatic child, frosted glass opacity was observed in his radiological examination. Therefore, in case of doubt, only clinical findings may not be sufficient for diagnosis.

The clinical course of COVID-19 is generally milder in children than in adults. It can range from asymptomatic infection to severe respiratory distress in newborns and children. Critical and severe cases were higher in groups under 1 year and under 5 years. Patients with critical condition and rapidly developing respiratory failure who need invasive mechanical ventilation generally have an underlying disease history. It appeared in 7-months-old patient with intensive care need hydronephrosis, receiving chemotherapy treatment for leukemia, having intussusception (37), congenital heart disease and moderate malnutrition; and in a 13-month-old patient with hydronephrosis and left kidney stone (38). Following the intensive care follow-up and multiorgan dysfunction in a 55-day-old baby with an unknown underlying disease, on the $11^{\text {th }}$ day, the clinical picture started to improve and patient discharged (39). Focal pneumonia finding in computerized tomography (CT) scan in children (4/10) also improved without requiring additional oxygen therapy (35). $1.6-2.5 \%$ of 123 children reported in the USA were hospitalized, and none of them needed intensive care (9).

Six child deaths, the diagnosis of which was clarified until March 29, 2020, were reported. Deaths of 10-months-old with intussusception and multiorgan failure (36), 14-years-old whose data are not clearly explained in the study (37), 3-years-old with leukemia in Iran, 6-yearsold with asthma and 35-days-old with no information (40), and a child under 1 year in Chicago, 12-years-old girl in Belgium and a 13-year-old male in England has been reported $(41,42)$. 
The lowest APGAR scores of the newborns were $8 / 9$ in the study, which was followed by 9 pregnant women who had a cesarean with symptomatic COVID-19 without severe COVID-19 pneumonia. In SARS infection, pregnant women infected with SARS-CoV-2 were monitored more closely because $50 \%$ of pregnant women needed intensive care, $33 \%$ received mechanical ventilation support, and the mortality rate in this group of patients was $25 \%$ higher than the population. However, none of the pregnant women needed intensive care.

Data on newborns are limited. While a 17 day newborn had symptoms of fever, cough and vomiting, the asymptomatic 30 hour newborn born from a mother infected with the SARS-CoV-2 was diagnosed with a viral nucleic acid test. In another newborn, whose mother was infected with SARS-CoV-2, fever occurred on its $5^{\text {th }}$ day of birth, vital signs of these newborns remained stable, and no severe or emergency occured $(43,44)$.

The classification of the clinical picture of the patients provides guidance for the course of the disease and treatment needs. Clinical condition classification (45):

1. Asymptomatic - silent - infection

Pediatric patients with positive SARS-CoV-2 RT-PCR test without clinical symptoms or abnormal pulmonary imaging

\section{Acute upper respiratory tract symptom findings}

Only in the presence of cough, fever, sore throat, nasal congestion, fatigue, headache, myalgia and weakness without the appearance of pneumonia or sepsis on pulmonary imaging.

\section{Mild pneumonia}

In the presence or absence of fever, respiratory system symptoms such as cough and symptoms indicating pneumonia from pulmonary imaging and in the period that have not met the criteria for severe pneumonia.

\section{Severe pneumonia}

In the presence of one of the following criteria:

- Increased respiratory rate: 70/min respiratory rate under 1-year-old, sedated over 1-year-old and over 50/min without fever,

- Oxygen saturation: $<92 \%$,

- In the presence of hypoxia symptoms: nasal wing breathing, difficult respiratory symptoms such as moaning, cyanosis, intermittent apnea, etc,

- Consciousness disorders; somnolence, coma, or convulsion,

- Symptoms of dehydration with difficulty feeding or food rejection.

\section{Critical cases}

In the presence of one of the following criteria and need of intensive care:

- Respiratory failure requiring mechanical ventilation support,

- Shock,

- Accompanied by other organ failures.

\section{Laboratory Evaluation}

The leukocyte count is normal (69.2\%) or decreased in the early stage of the disease. $4.6 \%$ neutrophilia and $6 \%$ neutropenia were observed (46). The lymphocyte count is reduced and lymphopenia deepens as the severity of the disease increases. Lymphopenia may be rarely seen in very young children depending on the immune system response $(47,48)$.

Increased liver enzymes and raise in inflammatory indicators such as C-reactive protein (CRP), procalcitonin (PCT), erythrocyte sedimentation rate (ESR), sometimes hyperglycemia have been detected in studies coducted on adults (48). Most children cases have high CRP and ESR levels and normal PCT levels. PCT and CRP increase was seen in $13.6 \%$ and $10 \%$ of the patients, respectively (46). It is recommended that attention should be paid to increase in PCT in children in terms of coinfection (8/20: 40\%) -influenza A and B viruses, mycoplasma, RSV and cytomegalovirus- (49). Bacterial coinfections should also be noted. In severe cases, high D-dimer levels are remarkable. Liver, muscle enzymes, troponin I, LDH levels and myohemoglobin levels have increased in some patients $(39,45)$. IL-6 level which also increases in viral diseases may be high during the course of disease in critically ill patients. It may be useful to follow up with the number of CRP and lymphocytes as a prognostic marker (46). Higher plasma cytokines IL-2, IL-7, IL-10, G-CSF, IP10, MCP1, MIP1A and TNF- $\alpha$ (cytokine storm) in adult patients in intensive care than patients in non-intensive care units were measured (50).

SARS-CoV-2 nucleic acid test positivity in nasopharyngeal swab, sputum, lower respiratory tract secretions, stool and blood samples are diagnostic tests. Although nasopharyngeal swab is the most commonly used test, it provides less than $50 \%$ positivity. Repetitive tests are required (51).

\section{Imaging Methods}

In diagnosed patients, pulmonary X-ray sensitivity is 59\%, CT sensitivity is 98\% and RT-PCR sensitivity is $71 \%$ (52). In COVID-19 patients, findings in favor of the disease can be detected in lung imaging rate close to clinical and laboratory findings rate. Therefore, it is an important examination in the diagnostic approach. Viral pneumonia-like changes were detected in $70.4 \%$ of 134 children in lung imaging (38).

In suspicious and diagnosed cases, pulmonary X-ray should be performed as soon as possible. If necessary, pulmonary CT scan should be performed immediately. Multiple small plaques and interstitial changes in the lung periphery can be observed in the early stages of the disease, and bilateral multiple ground glass opacities and/or infiltrations in later stages. Bilateral pulmonary lesions (more than 50\%) are more common than unilateral lesions. Small nodular appearance and pleural effusion are much rarer. The halo sign around the lesion is more specific to pediatric patients. Lung consolidation exists in more serious cases (49).

In 81 adult patients' radiological findings, COVID-19 pneumonia tends to occur as air bronchograms, peripheral infiltration and bilateral, subpleural, ground-glass opacities mostly in the right lower lobe in pulmonary CT scans. Abnormal pulmonary CT findings may be present even in asymptomatic patients. The lesions spread rapidly within 1-3 weeks after the onset of symptoms, and the frosted glass appearance 
increases or can turn into a consolidation pattern and peak approximately 2 weeks after the onset. Follow-up age, involvement characteristics in $\mathrm{CT}$, male gender, underlying comorbidities and progressive radiographic deterioration may be risk factors for poor prognosis in patients with COVID-19 pneumonia (53).

In the first newborn case with COVID-19 pneumonia, increased linear opacities were detected on pulmonary CT scan (43). The youngest patient, diagnosed with COVID-19, with viral pneumonia on CT scan without mild fever, is a 24 hour case (38).

Pneumomediastinum was detected in an adult CovID-19 patient's pulmonary CT scan following the development of respiratory distress during hospital follow-up. Spontaneous formation of pneumomediastinum in COVID-19 patients should be closely monitored as a potential indicator of ingravescent disease (54). The classification made by evaluating CTs of adult COVID-19 cases according to their periods (Table 3) will be useful for patient follow-up and staging (55).

\section{Diagnosis}

Clinic is often used for diagnosis. In the epidemiological study in China, laboratory values (normal or low white blood cell count, increased CRP) and abnormal chest $X$-ray were used for diagnosis in the presence of at least two symptoms (fever, respiratory symptoms, gastrointestinal symptoms or fatigue) (37).

Definitive diagnosis of COVID-19 is made using nasal or pharyngeal swabs or blood samples. RTS-PCR results should have been found positive by amplifying SARS-Cov-2 nucleic acid on the samples taken. Epidemiological data can be obtained by genetic sequencing. However, this test also has certain limitations; high false negative rates have also been reported. The use of rapid antibody test is also recommended to quickly identify a large number of infected patients and asymptomatic carriers in the fight against the virus. The measurement of IgM and IgG antibodies against SARS-CoV-2 virus in the blood of patients at different stages can be done by immunochromatographic card test within 15 minutes. The sensitivity of this test is $88.66 \%$ and its specificity is $90.6 \%$. This test can be used for rapid screening of symptomatic or asymptomatic SARS-CoV-2 vectors (56).

\section{Early Diagnosis of Critical Cases}

In the light of experiences from community-acquired pneumonia cases, those who had contact with infected cases or had a concomitant disease (congenital heart disease, bronchopulmonary hypoplasia, respiratory anomaly, severe malnutrition) or immune deficiency or immune compromised (prolonged use of immunosuppressants, etc) can be diagnosed early. Cases with this features are likely to become serious cases in the presence of one of the following criteria (45).

- Dyspnea: In the absence of sedation and no fever, respiratory rates to be $>50 / \mathrm{min}$ in 2-12 months old, $>40 / \mathrm{min}$ in $1-5$ years old, $>30 / \mathrm{min}$ in over 5 years old.

- Persistent high fever for 3-5 days,

- Low mental response, lethargy, mental fog and change,
- Increased enzyme levels (myocardial, liver enzymes and lactate dehydrogenase),

- Unexplained metabolic acidosis,

- Infiltration in bilateral or multiple lobes, lung imaging with pleural effusion, or rapid deterioration in general condition,

- Patients under 3 months,

- Extra pulmonary complications,

- Coinfection with other viruses and or bacteria.

\section{Differential Diagnosis}

Influenza, parainfluenza, adenovirus, RSV, rhinovirus, human metapneumovirus, SARS-CoV, other viral infections, mycoplasma pneumonia, chlamydia pneumonia and bacterial pneumonia are important in the differential diagnosis. The possibility of coinfection should also be considered during diagnosis (45).

\section{Patient Management}

Depending on their medical condition, suspicious patients should be isolated in a single room or at home. Cases with definitive diagnosis can be kept in the same area (in cohort) at home or hospital. Critical cases should be admitted to the intensive care unit as soon as possible. In case of a pandemic, national (Ministry of Health) algorithms must be followed (57-59).

Medical staff must protect themselves first. Hand hygiene should be provided with alcohol-based hand antiseptic. During the processes causing droplets or aerosolization, protective equipments are bone, goggles and face shield, FFP2 (N95) or FFP3 mask, apron and if possible at least 2 layers of gloves. It is recommended to use in accordance with the dressing and take off algorithm (Figure 1) (23). Especially during operations that produce aerosols, it is necessary to minimize its spread and take protective measures (Table 2) (23).

If medication is required via the inhalation route, an aerochamber or metered dose inhaler may be used. During treatment with the nasal cannula, wearing a surgical mask on the cannula, attaching the bacteria virus filter suitable for the ventilator circuits, using the double circuit in the ventilator in which the expiratory air is not given outside, performing the operations that create an aerosol in a negative pressure room can reduce the risk. Maneuvers should be carried out to use the balloon mask as little as possible. If it is still necessary to use a balloon mask, a virus filter and PEEP valve should be installed between the mask and the balloon. Balloon mask should also be made in accordance with the e-c technique. Low pressure should be used and a transparent pouch should be used to prevent virus spread. Use of laryngeal mask instead of balloon mask may be a good choice in suitable patients. Using a video laryngoscope, if available, during intubation may increase the distance between the patient and the doctor. After the intubation tube passed the vocal cords, the cuff must be inflated using the cuff manometry. Aspiration should be performed with a closed system (23). It is important to make sufficient neuromuscular blockade to reduce aerosol production during interventions such as tracheal intubation and to perform the procedures smooth and uncomplicated. 


\section{Isolation for diagnosed pediatric patients;}

Inpatients need to be isolated in a single room, and those with high infectivity need to be isolated in a negative pressure ward. Attention should be paid to strict disinfection of children's stool and secretions. Outpatients should be isolated with the guidance of a doctor at home, under the supervision of the parents and treated under the supervision of the community and the doctor's remote guidance. In 14 days after the disease, isolation should be terminated by respecting SARS-CoV-2 nucleic acid in respiratory secretions at least 2 times with a negative result. In daily care, attention should be paid on regular ventilation of the room, 30 minutes each time, 2 times/day; the use of an appropriate size mask and hand cleaning are points to be considered. The patients should rest, drink plenty of water, and eat nutritious foods that are easy to digest and keep balanced diet. Wearing long-sleeved clothing can be good for hygiene. Latex gloves can be worn to hold secretions and contaminated paper towels. The waste is placed in a disposable bag, sealed, and a disinfectant is sprayed on the outer surface of the packaging bag before throwing it in the trash bin. The floor of other rooms in the house, various surfaces and toys should be wiped periodically with disinfectants containing chlorine (disinfectants must remain on the surface for 5 minutes). Children's used clothes, towels and sheets are thoroughly washed with hot soapy water.

\section{General Treatment}

General treatment mainly includes bed rest and supportive therapy. Ensuring adequate calorie and water intake; preservation of waterelectrolyte balance and homeostasis; monitoring vital signs and oxygen saturation; other necessary biochemical evaluations, including keeping the airways open and supplying oxygen when needed, following routine blood and urine tests, CRP, liver and renal function, myocardial enzyme levels and coagulation parameters, blood gas should be planned according to the patient's condition. Pulmonary imaging may need to be renewed intermittently. CT scan is recommended (45). For patients in critical condition, prophylaxis should not be forgotten for the risk of gastointestinal bleeding. In addition, besides mechanical protection measures such as variable air pressure beds to protect the patient against venous thromboembolism, pharmacological prophylaxis (preferably low molecular weight heparin or heparin 5000 units can be applied under the skin 2 times a day) can be performed in adolescents if there are no contraindications (60).

\section{Symptomatic Treatment}

Patients with high fever are closely monitored. In cases exceeding 38.5 ${ }^{\circ} \mathrm{C}$, physical cooling (warm water bath, antipyretic patch use etc) or antipyretic drug treatment should be performed. Orally administered ibuprofen 5-10 mg/kg/dose and acetaminophen 10-15 mg/kg/dose are used. Rapid treatment should be performed in case of convulsions or seizures (45).

There are thoughts about the use of ibuprofen, even if it has not been clarified, that it facilitates the formation of the infection. Some clinicians defend the use of acetaminophen as antipyretic because they think that the early use of non-steroidal anti-inflammatory drugs (NSAIDs) has negative effects on the course of the disease. With these concerns and results from the studies conducted with a small number of young patients suggested that NSAID drugs increased disease severity with the theory that they had negative effects on the patient's immune response. The European Medicines Agency and WHO do not block the use of NSAIDs within clinical indications (61-64).

\section{Oxygen Treatment}

When hypoxia occurs, effective oxygen therapy, including nasal cannula, oxygen mask should be performed immediately. Nasal high flow oxygen therapy and noninvasive or invasive mechanical ventilation should be performed when necessary. In non-invasive methods, caution should be exercised in terms of droplet and aerosolization and the risk of late invasive treatment. Information can be obtained from WHO's manual for respiratory support and ARDS management $(23,60)$.

\section{Pharmacotherapy}

There is no proven specific treatment for the treatment of COVID-19 patients until results of ongoing clinical trials are revealed. However, since none of these treatments shows significant benefit in the treatment of other coronaviruses (MERS, SARS, etc), it is suspected to be tried in COVID-19 treatment. WHO and The Centers for Disease Control and Prevention (CDC) does not recommend any specific treatment in children or adolescents. However, in the case series mentioned earlier, $59 \%$ of 34 children diagnosed with COVID-19 were administered with Lopinavir (LPV)/Ritonavir (RTV) treatment. None of the children received glucocorticoid or immunoglobulin (65).

\section{Antiviral Treatment}

While interferons are used in viral respiratory diseases; LPV/RTV and arbidol are used in treatment of Human Immmunodeficiency Virus (HIV); oseltamavir is used in the treatment of influenza. Antiviral treatment should be administered only in critical cases. Reducing symptoms and maintaining immune balance is the main target (38).

\section{Interferon (IFN)- $\alpha$}

Interferon (IFN)- $\alpha$ can reduce viral load in the early stage of infection; it can help alleviate symptoms and shorten the duration of the disease. Based on our clinical research and experience of using IFN- $\alpha$ in the treatment of bronchiolitis, viral pneumonia, acute upper respiratory tract infection, foot and mouth disease, SARS and other viral infections in children, the recommended use is as follows (66-71):

1. IFN- $\alpha$ nebulization: In $2 \mathrm{~mL}$ of sterile water, IFN- $\alpha 200,000-400,000$ IU/kg or 2-4 $\mu \mathrm{g} / \mathrm{kg}$, nebulization twice daily for 5-7 days,

2. IFN- $\alpha 2$ b spray: It is applied to the high-risk population in close contact with patients suspected of being infected with SARS-CoV-2, or patients who have been diagnosed only at an early stage with upper respiratory symptoms. 1-2 sprays should be used on both sides of the nasal cavity and 8-10 sprays on the oropharynx. The interferon- $\alpha 2 b$ dose per application is 8,000 IU, it is applied every 1-2 hours, 8-10 sprays per day, for 5-7 days. Since IFN- $\alpha 2$ b nebulization is applied in MERS - CoV and SARS-CoV, it may be considered for COVID-19 infection (72).

In a study published by the Zhejiang University School of Medicine, nebulized IFN- $\alpha 2 b$ for children, LPV/RTV with corticosteroids for 
complications (ARDS, encephalitis, hemophagocytic syndrome or septic shock), and intravenous immunoglobulin for severe cases are recommended (73).

\section{Lopinavir/Ritonavir (Kaletra ${ }^{\circledR}$ )}

It is a protease inhibitor used in the HIV treatment. LPV is usually combined with RTV to increase the half-life of LPV by inhibition of cytochrome P450. It has been tried to apply in the treatment of adult patients with COVID-19 pneumonia, but its effectiveness and safety are still unclear $(74,75)$.

A successful case of MERS - CoV disease has been reported in South Korea who is treated with triple combination therapy LPV/RTV/ribavirin and IFN- $\alpha$ (74). The efficiency and safety of combined LPV/RTV/ribavirin therapy is still being evaluated in clinical studies and pediatric cases need to be treated more cautiously. In critical and appropriate cases, it can be considered if it is suitable for children. It can be dosed considering the anti-HIV treatment in children. HIV antigen/antibody should be checked before starting the medication.

LPV 250 mg / RTV 50 mg blister strip is used orally, twice daily for 5 days. Oral liquid form with LPV content of $16 \mathrm{mg} / \mathrm{kg}$ is recommended in children between 14 days- 6 months (57). Between 6 months- 18 years; $200 \mathrm{mg}-50 \mathrm{mg}$ in the range of 15-25 kilograms, $300 \mathrm{mg}-75 \mathrm{mg}$ in the range of 26-35 kilograms, $400 \mathrm{mg}-1000 \mathrm{mg} 2$ times a day if more than 35 kilograms (57).

LPV/RTV is safe in pregnant women in category $C$, syrup and tablet forms are available $(76,77)$.

\section{Remdesivir}

Remdesivir (GS5734) is an RNA polymerase inhibitor, adenosine nucleotide analogue with in vitro activity against multiple RNA viruses, including SARS, Ebola, MERS-CoV, SARS-CoV-2, both in vitro and animal studies (78). The pneumonia and general condition disorder developed in the first adult case in the USA improved after treatment with remdesivir. However, since this is limited to only one adult case, efficiency needs to be further verified (27). It is thought that it may be effective for both prophylaxis and treatment of human coronavirus infections (79).

Drugs considered to be effective against SARS-CoV-2, such as remdesivir or LPV-RTV, should be considered as rescuer therapy. It is suitable to be used after examining the profit-loss ratio, benefit and features as in adults. The pharmacology of intravenous remdesivir is unknown, phase 3 studies are ongoing and may not be possible as it is not licensed (80).

Adult use is recommended as $200 \mathrm{mg}$ intravenously in a lump, and then $100 \mathrm{mg}$ intravenously daily for 5-10 days (81). For children weighing less than 40 kilograms, following $5 \mathrm{mg} / \mathrm{kg}$ intravenous loading, $2.5 \mathrm{mg} / \mathrm{kg}$ once a day; and for children weighing more than 40 kilograms, $100 \mathrm{mg}$ intravenously is once a day following $200 \mathrm{mg}$ intravenous loading.

\section{Arbidol, Oseltamivir and Other Anti-influenza Drugs}

Arbidol is administered for adults infected with SARS-CoV-2; however, its effectiveness and safety remain uncertain. It has been discovered that Arbidol can block viral fusion of influenza A and B viruses, as well as hepatitis C virus (82). Oseltamivir and other anti-influenza agents can be administered in the presence of coinfection with the influenza virus. In case of clinical necessity, the dose of oseltamavir can be administered for 5 days, in accordance with the dosage schedule in influenza disease $(57,83)$.

\section{Ribavirin}

Ribavirin; is a guanosine analogue. It is used in hepatitis C treatment. It has been shown to be ineffective and even harmful and hemolyzed against SARS-CoV and MERS-CoV (67,84-86).

It has been reported that ribavirin and IFN synergistically inhibit SARS$\mathrm{CoV}$ replication in animal and human cell lines. Given the adverse reactions and lack of in vitro efficacy, the use of ribavirin for COVID-19 treatment should be seriously considered, even in combination with other antiviral drugs (87).

The use of Ribavirin $200 \mathrm{mg}$ capsules in the presence of clinical indications: for children $2 \mathrm{~g}$ (30 mg/kg) loading dose and then $4 \times 1 \mathrm{~g}(17$ $\mathrm{mg} / \mathrm{kg} /$ every 6 hours $/ 4$ days) or $4 \times 0.5 \mathrm{~g}$ (8 mg/kg/every 8 hours/6 days), for a total of 10-14 days (57).

\section{Table 3. Progressive stages of computerized tomography imaging in COVID-19 infection (87)}

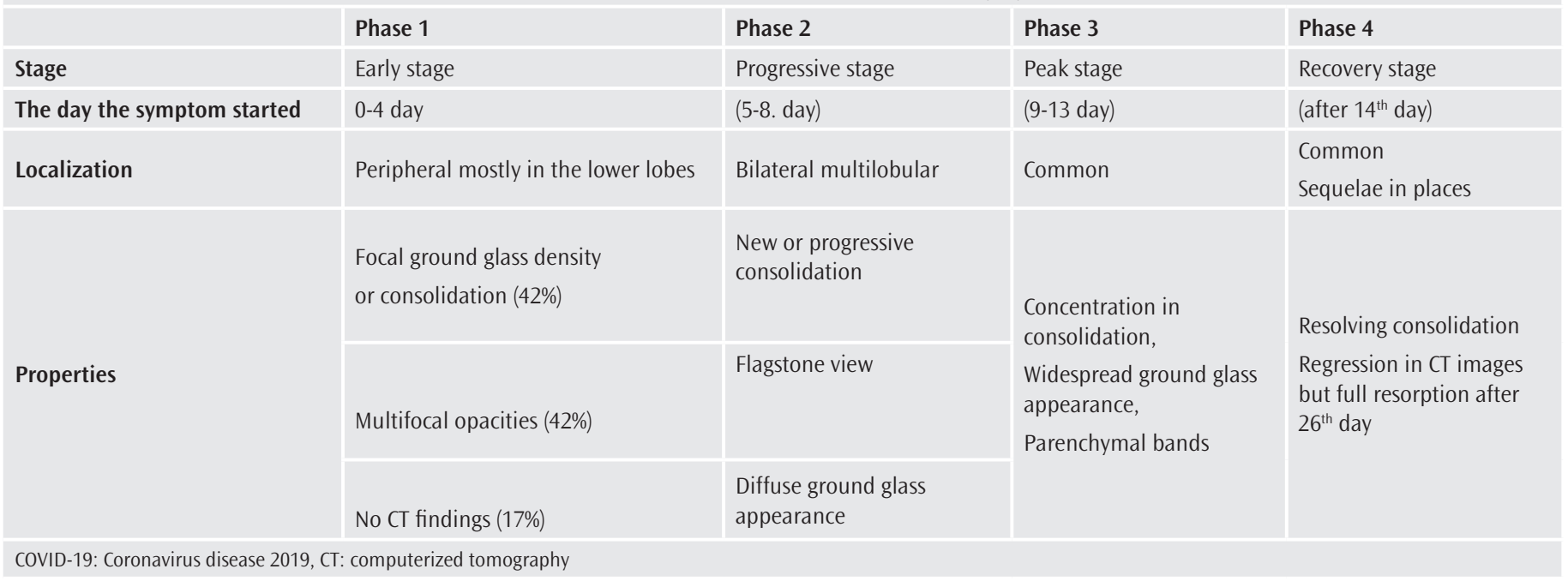




\section{Other Drug Treatments}

\section{Nafamostat}

In addition to being a short-acting anticoagulant that prevents clotting, it is a synthetic serine protease enzyme inhibitor with anti-cancer and anti-viral effects. It is used in pancreatitis treatment and renal disease. It is a potential inhibitor that prevents membrane fusion in MERS-CoV infection. Its use for SARS-CoV-2 is under trial $(88,89)$.

\section{Antibiotics}

In terms of bacterial or fungal coinfection, unnecessary use of antibiotics should be prevented by monitoring the patients closely. Antibiotics or antifungals should be used correctly and when necessary, with timely collection of samples for clinical status changes and pathogen analysis.

\section{Azithromycin}

Preliminary data evaluating the combination of hydroxychloroquine and azithromycin for the treatment of COVID-19 have been published recently. Combination therapy with azithromycin compared to the use of hydroxychloroquine only has more significant reduction in viral load. However, basal viral loads were higher in patients who received hydroxychloroquine monotherapy in the study. Despite this, the negation rate of tests on the sixth day of both groups was similar. It is recommended to avoid routine use due to insufficient data $(90,91)$.

For $1-5$ months old children $10 \mathrm{mg} / \mathrm{kg} /$ dose (maximum: $500 \mathrm{mg} / \mathrm{dose}$ ); for children over 6 months, $10 \mathrm{mg} / \mathrm{kg}$ in first day, single dose per day (maximum: $500 \mathrm{mg} /$ dose), followed by a single dose of $5 \mathrm{mg} / \mathrm{kg}$ per day for 2-5 days (maximum: $250 \mathrm{mg} /$ dose), it is recommended to administer a total of 5 days.

\section{Anakinra and Tocilizumab}

In adults, COVID-19 produces secondary hemophagocytic lymphohistiocytosis (HLH; fulminant with multiorgan failure and hypercytokinemia with a mortality), except ARDS. Viral infections in adults are the most common cause of secondary $\mathrm{HLH}$ and occur in 3-7.3\% of sepsis cases. In studies conducted in China, it is thought that mortality may caused by virally induced hyperinflammation (92).

Anakinra which blocks IL-1 is beneficial in patients with hyperinflammation (93). In addition, the trial of tocilizumab used for IL-6 receptor blockade has been approved in adults $(91,93)$. There are studies regarding the curative effects of combined use of tocilizumab with chloroquine, especially on its cytokine storm. The dose is $12 \mathrm{mg} / \mathrm{kg}$ for children weighing less than 30 kilograms, and $8 \mathrm{mg} / \mathrm{kg}$ (maximum: $800 \mathrm{mg} /$ dose) for children weighing more than 30 kilograms (91).

\section{Glucocorticoids}

The use of glucocorticoids should be tailored to the severity of the systemic inflammatory response, the degree of dyspnea, the presence of ARDS, and progression in pulmonary imaging. Glucocorticoids are recommended as methylprednisolone at a dose not exceeding $2 \mathrm{mg} / \mathrm{kg}$ daily for a short period of time (3-5 days) $(45,60)$.

WHO and CDC do not recommend the use of glucocorticoids in patients with COVID-19 pneumonia unless there is a different indication in adult patients (eg. exacerbation of chronic obstructive pulmonary disease) (94). Glucocorticoids have been associated with an increased risk of mortality in influenza patients and delayed viral clearance in patients with MERS-CoV infection. Although it is widely used in the treatment of SARS, there is no evidence of its usefulness, as well as convincing evidence for its short- and long-term adverse effects (95).

There are differences between the results obtained in influenza, SARS and different viral pneumonia conditions. Due to the methodological limitations in the current evidence, the use of corticosteroids is controversial. It is known that there are potential risks associated with high-dose corticosteroids, such as secondary infections, longterm complications, and long-term viral scattering, in the treatment of COVID-19 pneumonia. However, in critical patients, excessive inflammation and cytokine-related lung damage can cause rapidly progressing pneumonia. The Chinese Thoracic Society has made recommendations on the use of corticosteroids in COVID-19 pneumonia. According to the expert consensus statement, the following basic principles should be followed when using corticosteroids (96):

- Before using corticosteroids, the benefits and harm should be reviewed;

- Corticosteroids should be used with caution in critical patients with COVID-19 pneumonia;

- For patients with hypoxemia due to underlying diseases or patients who take corticosteroids regularly for their chronic diseases, should be careful in case of more use of corticosteroids;

- Drug dose should be low-medium dose $(\leq 0.5-1 \quad \mathrm{mg} / \mathrm{kg}$ methylprednisolone or equivalent, daily) and should be used for a minimum period of time ( $\leq 7$ days).

\section{Intravenous Immunoglobulin}

Immunoglobulin can be used for indication in severe cases, but more research is needed for its effectiveness (97).

\section{Convalescent (Obtained from Recovered Patients) Plasma Support}

It may be beneficial to administer serum from patients who recovered and developed antibodies against COVID-19 infection to the patients infected with COVID-19. In a wide metaanalysis, it was observed that the same method was applied in SARS and mortality decreased (98).

\section{Chloroquine}

It is widely used in autoimmune diseases and especially against malaria. It inhibits virus-cell fusion by increasing endosomal $\mathrm{pH}$. Therefore, it shows a potential antiviral drug feature. It also affects the glycolysis of cellular receptors of SARS-CoV-2 (99). In in vitro studies, chloroquine

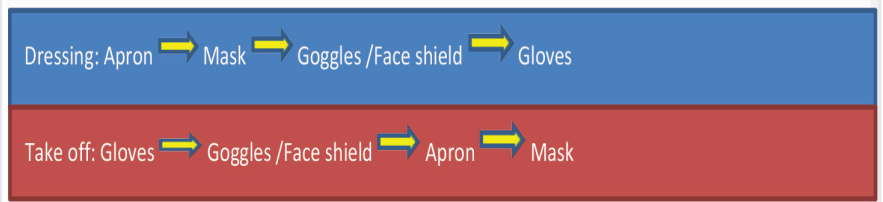

Figure 1. The order of wearing and take off personal protective equipment (95) 
inhibits the entry and following steps of SARS-CoV-2 into the cell. Chloroquine, being as in vitro, stabilizes the immunomodulatory activity by increasing the antiviral effect (100). Chloroquine is also an effective inhibitor of SARS infection by affecting the binding areas on cell surface for S protein of ACE-2 and SARS CoV (99). Suggested usage criteria are as follows: SARS-CoV-2 positivity and increased alanine aminotrans-ferase (ALT) or asportate aminotrans-ferase (AST) values 5 times higher than the upper limit or creatinine clearance $<50 \mathrm{~mL} / \mathrm{min}$ or non-pregnant patient receiving mechanical ventilation support.

The recommended dosage for moderate disease in adults; hydroxychloroquine tablets are recommended orally, $200 \mathrm{mg}$ twice a day, then $200 \mathrm{mg}$ once a day for 4 days, or $250 \mathrm{mg}$ twice a day for 5 days (81). The dose in children is $10 \mathrm{mg} / \mathrm{kg}$, twice a day (maximum: $600 \mathrm{mg} / \mathrm{dose}$ ) after loading 3 mg/kg (maximum: $200 \mathrm{mg} /$ dose) 3 times a day for 4 days, totally 5 days (57).

The time can be extended in case of prolonged ventilation or deep immunosuppression (91). It should be noted that hydroxychloroquine prolongs QTc in electrocardiography (ECG). Basal ECG should be taken. Dose adjustment is not required in renal or liver disorders.

\section{Mefloquine}

It is an antimalarial agent, whose effectiveness has not been proven yet, especially in Russia.

\section{Nitric 0xide}

It is a selective vasodilator. It can be effective in the case of ARDS, which can be a complication of SARS-CoV-2. The use of inhaled nitric oxide in the SARS-CoV epidemic reduced pulmonary hypertension, cured severe hypoxia, and reduced the duration of ventilation support. Studies on its use in COVID-19 are ongoing. It is applied as 30 ppm on the first day, $20 \mathrm{ppm}$ on the $2^{\text {nd }}$ day and $10 \mathrm{ppm}$ on the $3^{\text {rd }}$ day and decreases with oxygenation control with $10 \mathrm{ppm}$ on the $4^{\text {th }}$ day $(101,102)$.

\section{Drugs in Different Combinations}

In addition, three different potential drug combinations (sirolimus and dactinomycin, mercaptopurine and melatonin, toremifene and emodin) are candidates for use (103).

Certain drugs whose effectiveness has been investigated by clinical trials in COVID-19 treatment are shown in Table $4(13,57,91,104)$.

\section{Treatment of Severe and Critical Cases}

In accordance with the symptomatic treatment bases, preventive therapy, complication therapy, treatment of underlying conditions, treatment of secondary infections and, in case of indication organ functions oriented support should be provided.

\section{Respiratory and Circulatory Support}

Children with no change in their condition despite receiving noninvasive ventilation support for 2 hours, or children who are unable to tolerate noninvasive ventilation, have increased secretions, and have severe cough or hemodynamically unstable should be immediately taken to invasive mechanical ventilation support. In invasive mechanical ventilation, a low tidal volume "lung protective ventilation strategy" should be adopted to reduce lung damage associated with the ventilator. If necessary, ventilation in the prone position, lung recruitment maneuvers or extracorporeal membrane oxygenation (ECMO) can be performed. It is recommended to regulate microcirculation with full fluid support, use of vasoactive drugs, and when necessary, monitor hemodynamic data (60).

ECMO therapy is used as a life-saving approach in resistant ARDS cases. In a study of 6 adult patients who received ECMO treatment, 5 of the patients (83\%) died. Even if this number is small, it emphasized certain points to be considered on the application of ECMO therapy. During ECMO therapy, lymphopenia deepened and lymphocyte function impaired. The progressive increase in IL-6 level was thought to be secondary to parenchymal damage during ECMO. This increase is correlated with mortality. Therefore, monitoring the close lymphocyte count and IL-6 level is recommended. IL-6 levels of survivors after ECMO have reached their normal levels in a short time (47). In COVID-19 disease, while keeping in mind that the immune system is significantly affected, the immunological status of the patients should be taken into consideration when selecting candidates for ECMO (105).

\section{Traditional Chinese Medicine}

This disease is in the category of epidemic in traditional Chinese medicine. Some traditional treatments have been made in China, depending on the patient's condition, local climatic characteristics and children's physical characteristics.

\section{Recommendations for the Care/Treatment of Neonates Exposed to COVID-19 Disease}

Neonatologists should wear their protective equipment (hats, glasses, protective clothing, gloves, N95 masks, etc) to revive newborns born from the confirmed and/or suspected COVID-19 mother. If the mother's SARS-CoV-2 test is positive, the newborn should be isolated and tested for SARS-CoV-2.

Routine corticosteroids are not recommended for all women with confirmed COVID-19 infection between $34^{\text {th }}$ and $37^{\text {th }}$ weeks of pregnancy. Considering the additional risk factors, it is recommended to follow the international recommendations regarding fetal lung maturation while discussing the benefit of this treatment between $34^{\text {th }}$ and $37^{\text {th }}$ weeks of gestation (106).

Although it is recommended in some studies to examine every critical patient in neonatal intensive care for COVID -19 and to monitor all of them in intensive care, there are different opinions on this issue (107). Testing not every intensive care newborn, but newborns from families infected with SARS-CoV-2 or exposed to other infected persons regardless of their symptoms prevents misuse of resources. Early diagnosis and early isolation are mandatory for SARS-CoV-2 control. If the newborn does not have a clinical need for isolation, it does not need to be monitored in intensive care (79).

As in MERS management, newborns infected with SARS-CoV-2 should be placed in negative pressure rooms or in rooms with highly efficient 
particulate air filters in outlet ventilation. Treatment mainly depends on the clinical experience of adult patients, as there are few pediatric cases. There is no specific drug treatment for newborns (108). Symptomatic and supportive therapy, oxygen support, pulmonary edema and oxygenation status should be followed closely and appropriate hydration should be performed. In addition, maintaining electrolyte and acid-base balance is the mainstay of treatment. In cases with severe ARDS, due to the lack of adequate evidence-based data, high dose pulmonary surfactant, inhaled nitric oxide, high frequency oscillatory ventilation and ECMO can be used, depending on the diagnosis and classification criteria.

WHO stated that late clamping of the umbilical cord does not increase the risk of transmission of pathogens from the mother to the fetus, even in any identified infection in the mother. Since vernix caseosa contains antimicrobial peptides, washing is not recommended in 24 hours after birth. After birth, it is recommended to minimize transmission from mother with COVID-19 to newborn. In order to prevent contact with respiratory secretions, the mother should pay attention to the use of masks and hand hygiene if there is no other feature in her clinical condition (109). It is not recommended to keep the mother and baby in isolation separately, except in situations that require intensive care. It is emphasized that being separated may cause negative effects on nutrition and attachment. Close monitoring of the newborn is recommended $(59,110)$. It is recommended that mother and baby be separated only by consulting a multidisciplinary board when necessary. Looking at the previous data for separation, although it is a standard practice in pulmonary tuberculosis, it is discussed in maternal influenza infection cases. Patients should be informed about potential risks and benefits (109).
Cases have been reported in 10 newborns born from an infected mother with the COVID-19 virus (25). Although all 9 infants tested once had negative results for COVID-19 infection, neonatal complications following fetal distress were probably secondary to maternal disease. The condition of 2 babies out of 10 has become critical: while 34-week and 6-day-old newborn, whose first complaint was moaning, continued to live with immunoglobulin, platelet, plasma support; 34-week and 5-day-old newborn, whose first complaint was tachycardia, died after going rapidly into disseminated intravascular coagulation and multiple organ failure, not responding to blood transfusions and symptomatic support therapy. For these reasons, maternal-infant couples affected by SARS-CoV-2 should be closely followed up and monitored. In case of symptom development, newborns should be admitted to the neonatal unit immediately and isolated by initiating supportive treatments if necessary.

\section{Criteria for Discharge}

Patients with definitive diagnosis can be discharged from isolation or transferred to the relevant departments for the treatment of other diseases if all the following criteria are met:

1. Body temperature in the normal range for more than 3 days,

2. Significant improvement of respiratory symptoms,

3. Negative respiratory SARS-CoV-2 nucleic acid test result 2 times in succession (sampling interval is at least 1 day).

In suspected patients, when the test of the respiratory tract pathogen nucleic acid is negative 2 times in succession, they can be discharged from the isolation (sampling interval is at least 1 day) (45).

Table 4. Certain drugs whose effectiveness is investigated by clinical trials in the treatment of COVID-19 $(13,57,91,104)$

\begin{tabular}{|c|c|c|c|}
\hline Baloxavir & Antiviral & $\begin{array}{l}\text { It is effective against influenza viruses. } \\
\text { No approved use }\end{array}$ & 80 mg po 1x1, 4 days \\
\hline $\begin{array}{l}\text { Chloroquine } \\
\text { Hydroxychloroquine }\end{array}$ & Antimalarial & $\begin{array}{l}\text { Activities shown in Vero E cells as in vitro. } \\
\text { Theoretically, it has an immunomodulating effect } \\
\text { for anti-inflammatory response to viral infections. } \\
\text { Limited data for prevention and treatment. } \\
\text { The results of the studies are expected. } \\
\text { Positive effects in a limited number of studies } \\
\text { using chloroquine and azithromycin have been } \\
\text { reported. Both drugs can cause QTc prolongation. }\end{array}$ & $\begin{array}{l}\text { Chloroquine phosphate: } \\
500 \mathrm{mg} \text { oral x2/day, } 10 \text { days } \\
\text { If }<50 \mathrm{~kg} 500 \mathrm{mg} \text { oral } \times 2 / \text { day for the first } 3 \text { days, } \\
\text { then } 500 \mathrm{mg} \text { oral one time for } 3-7 \text { days. } \\
\left.\text { Hydroxychloroquine (Plaquenil }{ }^{\circledR}\right) \text { : oral, } 2 \times 200 \mathrm{mg} \\
\text { first day and then } 1 \times 200 \mathrm{mg} 4 \text { days or } 2 \times 250 \mathrm{mg} \\
5 \text { days. The dose in children is } 10 \mathrm{mg} / \mathrm{kg} \text {, x2/day } \\
\text { (max: } 600 \mathrm{mg} / \text { dose) after loading, } 3 \mathrm{mg} / \mathrm{kg}(\mathrm{max} \text { : } \\
200 \mathrm{mg} / \text { dose) } \times 3 / \text { day, } 4 \text { days, total } 5 \text { days ( } 43 \text { ). }\end{array}$ \\
\hline $\begin{array}{l}\text { Lopinavir and Ritonavir } \\
\left.\text { (LPV/RTV; Kaletra }{ }^{\circledR}\right)\end{array}$ & HIV Protease Inhibitor & $\begin{array}{l}\text { It has different studies. It was found that it could } \\
\text { not decrease clinical recovery time, could not } \\
\text { decrease viral RNA load during viral DNA positivity, } \\
\text { did not have any positive effect on oxygen } \\
\text { treatment time or hospital stay and duration from } \\
\text { diagnosis to death. } \\
\text { More studies are needed for its combination with } \\
\text { different drugs. } \\
\text { The combined use with Ribavirin, Arbidol and } \\
\text { Interferon is being studied. }\end{array}$ & $\begin{array}{l}\text { Lopinavir } 250 \text { mg /Ritonavir } 50 \text { mg film tablet, } \\
\text { oral x2/day, } 5 \text { days. } \\
\text { Oral for } 14 \text { days- } 6 \text { months with Lopinavir } \\
\text { content of } 16 \text { mg kg. } \\
6 \text { months - } 18 \text { years of age; for } 15-25 \text { kg oral } 200 \\
\text { mg- } 50 \text { mg; } \\
\text { for } 26-35 \text { kg, } 300 \text { mg- } 75 \text { mg, for } \\
>35 \mathrm{~kg}, 400 \text { mg- } 1000 \text { mg x2/day. }\end{array}$ \\
\hline
\end{tabular}


Table 4. continued

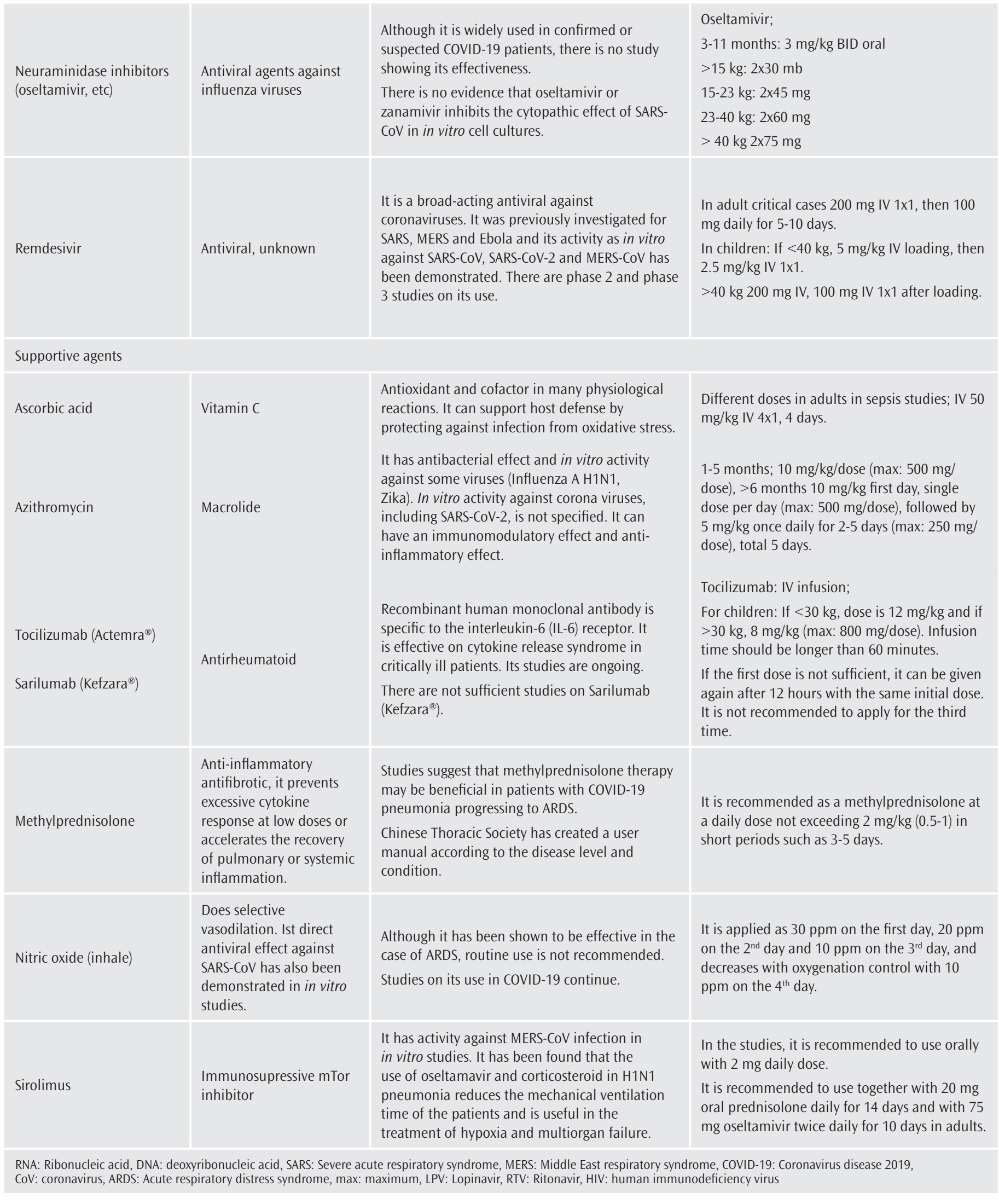




\section{Conditions Expected During Post-discharge and Isolation Period}

The secondary effects of closed schools and having children spend long periods at home should not be forgotten. It can be predicted that this will have negative effects on children's physical and mental condition. This can result in weight gain following long screen exposure, irregular sleep, unhealthy diets and a lack of movement (111).

In a study not related to the COVID-19 outbreak, tests were conducted by interviewing 398 families, and it was found that the risk of posttraumatic stress disorder increases when children are quarantined and isolated after health-related disasters (112).

Psychological counseling; plays an important role in disease recovery. If patients (especially older children) show mood swings, fear, or psychological disorders, active psychological intervention and treatment is required.

\section{Preventing Social Spread}

Infection source control, self-isolation of supercarriers, blocking the transmission routes and infection control applications with sensitive population protection are of great importance.

\section{Prophylaxis}

WHO recommended pre-contact prophylaxis before exposure to diseases such as pandemic influenza, invasive meningococemia, or for people at high risk of infection. It is effective in preventing disease after exposure to proven infection and reducing viral load in respiratory secretions, reducing the risk of secondary spread and transmission. In pharmacological models based on invitro tests performed until now, it is predicted that prophylaxis with appropriate doses of hydroxychloroquine against SARS CoV-2 can prevent infection and reduce viral spread. This information will become clear in May 2020 with the results of the study to be carried out in the Spain-Catalonia region $(113,114)$.

\section{Conclusion}

Close follow-up of the clinical findings of the pediatric patients and following the rules of isolation will provide a milder circumvention of the pandemic. In COVID-19; while children can usually progress with a mild clinic, children with underlying disease may have more severe pictures. More virological, epidemiological and clinical data are required for specific antiviral treatment and disease management for children.

\section{Ethics}

Peer-review: Externally peer-reviewed.

Author Contributions: Surgical and Medical Practices - H.E.M.A., Ö.Ö.; Concept - H.E.M.A., Ö.Ö. ; Design - H.E.M.A., Ö.Ö.; Data Collection or Processing - H.E.M.A., Ö.Ö. ; Analysis or Interpretation - H.E.M.A., Ö.Ö. ; Literature Search - H.E.M.A., Ö.Ö. ; Writing - H.E.M.A., Ö.Ö.

Conflict of Interest: No conflict of interest was declared by the authors.

Financial Disclosure: The authors declared that this study received no financial support.

\section{References}

1. World Health Organization. Novel coronavirus, China. 2020 https://www.who. int/csr/don/12-january-2020-novel-coronavirus-china/en/ (Accessed on March 19, 2020).

2. World Health Organization. Naming the coronavirus disease (COVID-19) and the virus that causes it. WHO Technical Guidance 2020. https://www.who.int/ emergencies/diseases/novel-coronavirus-2019/technical-guidance/namingthe-coronavirus-disease-(covid-2019)-and-the-virus-that-causes-it (Accessed on March 15, 2020).

3. Ashour HM, Elkhatib WF, Rahman MM, Elsabrawy HA. Insights into the Recent 2019 Novel Coronavirus (SARS-CoV-2) in Light of Past Human Coronavirus Outbreaks. Pathogens 2020; 9: 186

4. Favre G, Pomar L, Musso D, Baud D. 2019-nCoV epidemic: what about pregnancies? Lancet 2020; 395: 40

5. Memish Z, Perlman S, Kerkhove MDV, Zumla A. Middle East respiratory syndrome. Lancet 2020; 395: 1063-77.

6. Zhang YH, Lin DJ, Xiao MF, Wang JC, Wei Y, Lei ZX, et al. 2019-novel coronavirus infection in a three-month-old baby. Zhonghua Er Ke Za Zhi 2020; 58: E006.

7. Cai JH, Wang XS, Ge YL, Xia AM, Chang HL, Tian H, et al. First case of 2019 novel coronavirus infection in children in Shanghai. Zhonghua Er Ke Za Zhi 2020; 58: E002

8. Livingston E, Bucher K. Coronavirus Disease 2019 (COVID-19) in Italy. Jama 2020;323:1335

9. CDC COVID-19 Response Team. Severe outcomes among patients with coronavirus disease 2019 (COVID-19) United States, February 12-March 16, 2020. Weekly 2020; 69; 343-6.

10. Wu Z, McGoogan JM. Characteristics of and important lessons from the coronavirus disease 2019 (COVID-19) outbreak in china: summary of a report of 72314 cases from the chinese center for disease control and prevention. JAMA 2020; 323: 1239-42.

11. Korea Centers for Disease Control and Coordination. Updates on COVID-19 in Korea. 2020 March 14. https://www.cdc.go.kr/board/board. es? $\mathrm{mid}=\mathrm{a} 30402000000 \& \mathrm{bid}=0030$ (Accessed on March 18, 2020).

12. Woo PC, Huang Y, Lau SK, Yuen KY. Coronavirus genomics and bioinformatics analysis. Viruses 2010; 2: 1804-20.

13. Geller C, Varbanov M, Duval R. Human coronaviruses: insights into environmental resistance and its influence on the development of new antiseptic strategies. Viruses 2012; 4: 3044-68.

14. Perlman S. Another decade, another coronavirus. N Engl J Med 2020; 382 760-2.

15. Zhu N, Zhang D, Wang W, Li X, Yang B, Song J, et al. A novel coronavirus from patients with pneumonia in China, 2019. N Engl J Med 2020; 382: 727-33.

16. Jubeit B, Narayan 0, Johnson RT. Patognezis of human poliovirus infection in mice. Clinical and pathological studies. J Neuropathol Exp Neurol 1980; 39: 138-48.

17. Lee P. Are children less susceptible to COVID-19? Journal of Microbiol Immunol Infect 2020; 53: 371-2.

18. Gu H, Xie Z, Li T, Zhang S, Lai C, Zhu P, et al. Anjiotensin-converting enzyme 2 inhibits lung injury by respiratory syncytial virus. Scientific Reports 2016; 6: 19840

19. Zhao Y, Zhao Z, Wang Y, Zhao Y, Ma Y. Single-cell RNA expression profiling of ACE2, the putative receptor of Wuhan 2019-nCov. BioRxiv. 2020. doi: https:// doi.org/10.1101/2020.01.26.919985. [Epub ahead of print].

20. Liu J, Liu Y, Xiang P, Pu L, Xiong X, Li C, et al. Neutrophil-to-lymphocyte ratio predicts severe illness patients with 2019 Novel Coronavirus in the early stage. Med Rxiv 2020 
21. Cao Q, Chen YC, Chen LC, Chiu CH. SARS-CoV-2 infection in children: Transmission dynamics and clinical characteristics. Journal of the Formosan Medical Association 2020; 119: 670-3.

22. Doremalen VN, Bushmaker T, Morris DH, Holbrook MG, Williamson BN, Tamin A, et al. Aerosol and surface stability of SARS-CoV-2 as compared with SARS-CoV-1. N Engl J Med 2020; 382: 1564-7.

23. Anıl M, Besli E, Duman M, Erkek N, Derinöz O, Tekin D et al. Çocuk acil servisi CoVID-19 olgu yönetim algoritmaları. Çocuk acil tıp ve yoğun bakım derneği yayınları 2020; 1: 1.

24. Chen C, Guo J, Wang C, Luo F, Yu X, Zhang W, et al. Clinical characteristics and intrauterine vertical transmission potential of COVID-19 infection in nine pregnant women: a retrospective review of medical records. Lancet 2020; 395: 809-15.

25. Zhu H, Wang L, Fang C. Clinical analysis of 10 neonates born to mothers with 2019-nCoV pneumonia. Transl Pediatr 2020; 9: 51-60.

26. Dong L, Tian J, He S, Zhu C, Wang J, Liu C, Possible vertical transmission of sars-cov-2 from an infected mother to her newborn. research letter. JAMA 2020; 323: 1846-8

27. Holshue ML, DeBolt C, Lindquist S, Lofy KH, Wiesman J, Bruce H, et al. First case of 2019 novel coronavirus in the United States. N Engl J Med 2020; 382: 929-36.

28. Chan JF, Yuan S, Kok KH, To KKW, Chu H, Yang J, et al. A familial cluster of pneumonia associated with the 2019 novelcoronavirus indicating person-toperson transmission: a study of a family cluster. Lancet 2020; 395: 514-23.

29. Chen C, Gao G, Xu Y, Pu L, Wang Q, Wang L, et al. SARS-CoV-2-Positive sputum and feces after conversion of pharyngeal samples in patients with COVID-19. Ann Intern Med 2020: 20-0091.

30. Wang L, Li X, Chen H, Yan S, Li Y, Li D, et al. SARS-CoV-2 infection does not significantly cause acute renal injury: an analysis of 116 hospitalized patients with COVID-19 in a single hospital, Wuhan, China. Med Rxiv 2020.

31. Liu Y, Yan L, Wan L, Xiang TX, Le A, Liu JM, et al. Viral dynamics in mild and severe cases of COVID-19. The Lancet Infect Dis 2020; 20: 656-7.

32. Lauer SA, Grantz KH, Bi Q, Jones FK, Zheng Q, Meredith $\mathrm{H}$, et al. The incubation period of 2019-nCoV from publicly reported confirmed cases: estimation and application. Med Rxiv 2020: 20-0504.

33. Lu X, Zhang L, Du H, Shao J, Peng X, Liu Z, et al. SARS-CoV-2 infection in children. N Engl J Med 2020; 382: 1663-5.

34. Liu W, Zhang Q, Chen J, Xiang R, Song H, Liang L, et al. Detection of covid-19 in children in early january 2020 in Wuhan, China. N Engl J Med 2020; 382: 1370-1.

35. Cai J, Xu J, Lin D, Yang Z, Xu L, Qu Z, et al. A case series of children with 2019 novel coronavirus infection: clinical and epidemiological features. Clin Infect Dis. 2020 February. doi:10.1093/cid/ciaa198.

36. Ji L, Chao S, Wang Y, Li XJ, Mu XD, Lin MG, et al. Clinical features of pediatric patients with COVID19: a report of two family cluster cases. World J Pediatr 2020: 1-4.

37. Dong Y, Mo X, Hu Y, Qi X, Jiang F, Jiang Z, et al. Epidemiological characteristics of 2143 pediatric patients with 2019 coronavirus disease in china. Pediatrics 2020.

38. Yang P, Liu P, Li D,Zhao D. Corona virus disease 2019, a growing threat to children? J Infect 2020; 80: 671-93.

39. Cui Y, Tian M, Huang D, Wang X, Yuying H, Fan L, et al. A 55-day-old female infant infected with covid 19: presenting with pneumonia, liver injury, and heart damage. J Infect Dis 2020; 221: 1775-81.

40. Available from URL: https://irannewsdaily.com/2020/03/iran-35-day-oldbaby-tests-positive-for-covid-19/website. with-covid-19/6058789/ (Accessed on March 19, 2020).
41. Available from URL: https://abc11.com/health/illinois-reports-death-ofinfant-with-covid-19/6058789/ (Accessed on March 19, 2020).

42. https://www.channelnewsasia.com/news/world/coronavirus-covid-19-ukboy-dies-12596462?utm_source=headtopics\&utm_medium=news\&utm_ campaign=2020-04-01 (Accessed on March 19, 2020).

43. Zeng LK, Tao XW, Yuan WH, Wang J, Liu X, Liu ZS. First case of neonate infected with novel coronavirus pneumonia in China. Chin J Pediatr 2020; 58: 009.

44. Deng H, Zhang Y, Wang Y, Li F. Two cases of 2019 novel coronavirus infection in children. Chin Pediatr Emerg Med 2020; 27: E001-E001.

45. Shen K, Yang Y, Wang T, Zhao D, Jiang Y, Jin R, et al. Diagnosis, treatment, and prevention of 2019 novel coronavirus infection in children: experts consensus statement. World J Pediatr 2020

46. Henry BM, Lippi G, Plebani M. Laboratory abnormalities in children with novel coronavirus disease 2019. Clin Chem Lab Med 2020.

47. Yang X, Yu Y, Xu J, Shu H, Xia J, Liu H, et al. Clinical course and outcomes of critically ill patients with SARS-CoV-2 pneumonia in Wuhan, China: a singlecentered, retrospective, observational study. Lancet Respir Med 2020; 8: 47581.

48. Chen N, Zhou M, Dong X, Qu J, Gong F, Han Y, et al. Epidemiological and clinical characteristics of 99 cases of 2019 novel coronavirus pneumonia in Wuhan, China: a descriptive study. Lancet 2020; 395: 507-13.

49. Xia W, Shao J, Guo Y, Peng X, Li Z, Hu D. Clinical and CT features in pediatric patients with COVID-19 infection: Different points from adults. Pediatr Pulmonol 2020; 55: 1169-74

50. Huang C, Wang Y, Li X, Ren L, Zhao J, Hu Y, et al. Clinical features of patients infected with 2019 novel coronavirus in Wuhan, China. Lancet 2020; 395: 497506.

51. Gao ZC. Efficient management of novel coronavirus pneumonia by efficient prevention and control in scientific manner. Zhonghua Jie He He Hu Xi Za Zhi 2020; 43: 163-6.

52. Ai T, Yang Z, Hou H, Zhan C, Chen C, Lv W, et al. Correlation of chest CT and RT-PCR testing in coronavirus disease 2019 (COVID-19) in China: a report of 1014 Cases. Radiology. 2020. doi: 10.1148/radiol.2020200642. [Epub ahead of print].

53. Shi H, Han X, Jiang N, Cao Y, Alwalid O, Gu J, et al. Radiological findings from 81 patients with COVID-19 pneumonia in Wuhan, China: a descriptive study. Lancet 2020; 20: 425-34.

54. Zhou C, Gao C, Xie Y. COVID-19 with spontaneous pneumomediastinum. Lancet 2020; 20: 510

55. Pan F, Ye T, Sun P, Gui S, Liang B, Lingli L, et al. Time course of lung changes on chest CT during recovery from 2019 novel coronavirus (COVID-19) pneumonia. Radiology 2020; 295: 200370.

56. Li Z, Yi Y, Luo X, Xiong N, Liu Y, Li S, et al. Development and clinical application of a rapid igm-igg combined antibody test for SARS-CoV-2 infection diagnosis. J Med Virol 2020

57. TC Sağlık Bakanlığı Halk Sağlığı Genel Müdürlüğü COVID -19 (SARS-CoV2 Enfeksiyonu) Rehberi. Bilim kurulu çalıșması. 2020 Mar 23. (Accessed on March 25, 2020).

58. Sağlık Bakanlığı Ulusal CoVID-2 acile kabul algoritması, T.C. Sağılı Bakanlığı, 2020 Mar. (Accessed on March 25, 2020).

59. Sağlık Bakanlığı Ulusal CoVID-2 tanı tedavi takip algoritması, T.C. Sağlık Bakanlığı, 2020 Mar. (Accessed on March 25, 2020).

60. World Health Organization. Clinical management of severe acute respiratory infection (SARI) when COVID-19 disease is suspected. Interim guidance 2020 Mar 13. Avaliable fom URL: https://www.who.int/publications-detail/clinicalmanagement-of-severe-acute-respiratory-infection-when-novel-coronavirus(ncov)-infection-is-suspected. (Accessed on March 15, 2020). 
61. Available from URL: https://dgsurgent.sante.gouv.fr/dgsurgent/inter/ detailsMessageBuilder.do?id=30500\&cmd=visualiser Message (Accessed on March 19, 2020).

62. Day M. Covid-19: ibuprofen should not be used for managing symptoms, say doctors and scientists. BMJ 2020; 368: m1086.

63. World Health Organization. Now Doesn't Recommend Avoiding Ibuprofen For COVID-19 Symptoms. Science Alert 2020. Available from URL: https://www. sciencealert.com/who-recommends-to-avoid-taking-ibuprofen-for-covid-19symptoms. March 2020. (Accessed on March 25, 2020).

64. European Medicines Agency. EMA gives advice on the use of non-steroidal antiinflammatories for COVID-19. Available from URL: https://www.ema.europa. eu/en/news/ema-gives-advice-use-non-steroidal-anti-inflammatoriescovid-19. 2020 Mar. (Accessed on March 25, 2020).

65. Wang XF, Yuan J, Zheng YJ, Chen J, Bao YM, Wang YR, et al. Clinical and epidemiological characteristics of 34 children with 2019 novel coronavirus infection in Shenzhen. Zhonghua Er Ke Za Zhi 2020; 58: E008.

66. Wang BX, Fish EN. Global virus outbreaks: interferons as 1st responders. Semin Immunol 2019; 43: 101300.

67. Al-Tawfiq JA, Momattin H, Dib J, Memish ZA. Ribavirin and interferon therapy in patients infected with the Middle East respiratory syndrome coronavirus: an observational study. Int J Infect Dis 2014; 20: 42-6.

68. Shen KL, Shang YX, Zhang GC, Xu BP, Fu Z, Cao L, et al. Expert consensus on rational application of interferon $\alpha$ in pediatrics. Chin J Appl Clin Pediatr 2018; 33: 1301-8.

69. Xu YL, Li Y, Chen YP, Xin SX, Xie L, Liang YD, et al. A multicenter controlled clinical study on the efcacy and safety of recombinant human interferon $\alpha 2 b$ spray in the treatment of hand, foot and mouth disease in children. Chin J Infect 2018; 36: 101-6.

70. Shen KL, Shang YX, Zhang H. A multicenter, randomized, controlled clinical study on the efcacy and safety of recombinant human interferon $2 \mathrm{~b}$ spray (pseudomonas) in the treatment of acute upper respiratory tract infection in children. Chin J Appl Clin Pediatr 2019; 34: 1010-6.

71. Gao H, Zhang LL, Wei Q, Duan ZJ, Tu XM, Yu ZA, et al. Preventive and therapeutic effects of recombinant IFN- $\alpha 2 b$ nasal spray on SARS-CoV infection in Macaca mulata. Chin J Exp Clin Virol 2005; 19: 207-11.

72. Khalid M, Al Rabiah F, Khan B, Al Mobeireek A, Butt TS, Al Mutairy E. Ribavirin and interferon- $\alpha 2 b$ as primary and preventive treatment for Middle East respiratory syndrome coronavirus: a preliminary report of two cases. Antivir Ther 2015; 20: 87-91.

73. Chen ZM, Fu JF, Shu Q, Chen YH, Hua CZ, Li FB, et al. Diagnosis and treatment recommendations forpediatric respiratory infection caused by the 2019 novel coronavirus. World J Pediatr 2020: 1-7.

74. Kim UJ, Won EJ, Kee SJ, Jung SI, Jang HC. Combination therapy with lopinavir/ritonavir, ribavirin and interferon-alpha for Middle East respiratory syndrome. Antivir Ther 2016; 21: 455-9.

75. Çin Sağlık Halk Cumhuriyeti Ulusal Sağlık Kurulu. Yeni koronavirüs enfeksiyonu pnömoni tanı ve tedavi planı (deneme versiyonu 5) (2020/02/04 ) [ 2020/02/05.] http: //www.nhc.gov.cn / xcs / zhengcwj / 202001 /4294563ed35b43209b31739bd0785e67 / files / 7a9309111267475a99d4306962c8bf78.pdf (Accessed on March 20, 2020).

76. Luca DD. Managing neonates with respiratory failure due to SARS-CoV-2. Lancet 2020; 4: 8.

77. Sheahan TP, Sims AC, Leist SR, Schafer A, Won J, Brown AJ, et al. Comparative therapeutic efficacy of remdesivir and combination lopinavir, ritonavir, and interferon beta against MERS-CoV. Nat Commun 2020; 11: 222-3.

78. Wang M, Cao R, Zhang L, Yang X, Liu J, Xu M, et al. Remdesivir and chloroquine effectively inhibit the recently emerged novel coronavirus (2019-nCoV) in vitro. Cell Res 2020; 30: 269-71.
79. Gordon CJ, Tchesnokov EP, Feng JY, Porter DP, Gotte M. The antiviral compound remdesivir potently inhibits RNA-dependent RNA polymerase from Middle East respiratory syndrome coronavirus. J Biol Chem 2020; 1-13.

80. Gilead Sciences. Study to evaluate the safety and antiviral activity of Remdesivir (GS-5734) in participants with severe coronavirus disease (CoVID-2) Clinical Trials 2020 March. ClinicalTrials.gov. (Accessed on March 25, 2020).

81. Jackson Health System / University of Miami Health System .COVID-19 Confirmed or highly suspected-investigational treatment protocol, March 20,2020. https://jacksonhealth.org/coronavirus-disease-2019-covid-19/\#gref (Accessed on March 25, 2020).

82. Boriskin YS, Leneva IA, Pecheur El, Polyak SJ. Arbidol: a broad-spectrum antiviral compound that blocks viral fusion. Curr Med Chem 2008; 15 : 997-1005.

83. Lu H. Drug treatment options for the 2019-new coronavirus (2019-nCoV). Biosci Trends 2020; 14: 69-71.

84. Stockman LJ, Bellamy R, Garner P. SARS: Systematic review of treatment effects. PLoS Med 2006; 3: 343.

85. Omrani AS, Saad MM, Baig K, Bahloul A, Abdul-Matin M, Alaidaroos AY, et al. Ribavirin and interferon alfa-2a for severe Middle East respiratory syndrome coronavirus infection: a retrospective cohort study. Lancet Infect Dis 2014; 14: $1090-5$

86. Shalhoub S, Farahat F, Al-jiffri A, Simhairi R, Shamma O, Siddiqi N, et al. IFN$\alpha 2 a$ or IFN- $\beta 1$ a in combination with ribavirin to treat Middle East respiratory syndrome coronavirus pneumonia: a retrospective study. J Antimicrob Chemother 2015; 70: 2129-32.

87. Morgenstern B, Michaelis M, Baer PC, Doerr HW, Cinatl J. Ribavirin and interferon-beta synergistically inhibit SARS-associated coronavirus replication in animal and human cell lines. Biochem Biophys Res Commun 2005; 26 : 905-8.

88. Wang M, Cao R, Zhang L, Yang X, Liu J, Xu M, et al. Remdesivir and chloroquine effectively inhibit the recently emerged novel coronavirus (2019-nCoV) in vitro. Cell Res 2020; 30: 269-71.

89. Chen X, Xu Z, Zeng S, Wang S, Wang X, Liu W, et al. The molecular aspect of antitumor effects of protease inhibitor nafamostat mesylate and its role in potential clinical applications. Front Oncol 2019; 9: 852.

90. Gautret P, Lagier JC, Parola P, Hoang VT, Meddeb L, Mailhe M, et al. Hydroxychloroquine and azithromycin as a treatment of COVID-19: results of an open-label non-randomized clinical trial. Int J Antimicrob Agents 2020: 105949.

91. Michigan Medicine University of Michigan. Inpatient Guidance For Treatment of CoVID-19 in Adults and Children. http://www.med.umich.edu/asp/pdf/ adult_guidelines/COVID-19-treatment.pdf. (Accessed on March 25, 2020).

92. Mehta P, McAuley FD, Brown M, Sanchez E, Tattersall RS, Manson JJ. COVID-19: consider cytokine storm syndromes and immunosuppression. Lancet 2020; 395: 1033-4.

93. Shakoory B, Carcillo JA, Chatham WW, Amdur RL, Zhao H, Dinarello CA, et al. Interleukin-1 receptor blockade is associated with reduced mortality in sepsis patients with features of macrophage activation syndrome: reanalysis of a prior phase III trial. Crit Care Med 2016; 44: 275-81.

94. World Health Organization. Coronavirus disease (COVID-19) technical guidance: Patient management. Available from URL: https:/www.who.int/ emergencies/diseases/novel-coronavirus-2019/technical-guidance/patientmanagement (Accessed on February 02, 2020)

95. Russell CD, Millar JE, Baillie JK. Clinical evidence does not support corticosteroid treatment for 2019-nCoV lung injury. Lancet 2020; 395: 473.

96. Shang L, Zhao J, Hu Y, Du R, Cao B. On the use of corticosteroids for 2019-nCoV pneumonia. Lancet 2020; 395: 683-4. 
97. Dalakas MC, Clark WM. Strokes, thromboembolic events, and IVIG: Rare incidents blemish an excellent safety record. Neurology 2003; 60: 1736-7.

98. Mair-Jenkins J, Saavedra-Campos M, Baillie JK, Cleary P, Khaw FM, Lim WS, et al. The effectiveness of convalescent plasma and hyperimmune immunoglobulin for the treatment of severe acute respiratory infections of viral etiology: a systematic review and exploratory meta-analysis. J Infect Dis 2015; 211: 80-90.

99. Vincent MJ, Bergeron E, Benjannet S, Erickson BR, Rollin PE, Ksiazek TG, et al. Chloroquine is a potent inhibitor of SARS coronavirus infection and spread. Virol J 2005; 2: 69 .

100. Wang M, Cao R, Zhang L, Yang X, Liu J, Xu M, et al. Remdesivir and chloroquine effectively inhibit the recently emerged novel coronavirus (2019-nCoV) in vitro. Cell Res 2020; 30: 269-71.

101. Chen L, Liu P, Gao H, Sun B, Chao D, Wang F, et al. Inhalation of nitric oxide in the treatment of severely acute respiratory syndrome: a rescue trial in Beijing. Clin Infect Dis 2004; 39:1531-5.

102. Mallinckrodt Pharmaceuticals. Mallinckrodt Evaluates the Potential Role for Inhaled Nitric Oxide to Treat COVID-19 Associated Lung Complications, Engages with Scientific, Governmental and Regulatory Agencies. From the Prnewswire website. https://www.prnewswire.com/news-releases/ mallinckrodt-evaluates-the-potential-role-for-inhaled-nitric-oxide-to-treatcovid-19-associated-lung-complications-engages-with-scientific-governmental-and-regulatory-agencies-301022189.html (Accessed on March 24, 2020).

103. Zhou Y, Hou Y, Shen J, Huang Y, Martin W, Cheng F. Network-based drug repurposing for human coronavirus. Med Rxiv. Accessed on 2020 March 25. https://doi.org/10.1101/2020.02.03.20020263. [Epub ahead of print].

104. Pharmacists advancing healthcare. Assessment of Evidence for COVID-19Related Treatments. ASHP (Pharmacists advancing healthcare) guidance. 27 March 2020. https://www.ashp.org/Pharmacy-Practice/Resource-Centers/ Coronavirus (Accessed on March 29, 2020).
105. Henry BM. COVID-19, ECMO, and lymphopenia: a word of caution. Lancet Respir Med. 2020 March 13. doi: 10.1016/\$2213-2600(20)30119-3. (Accessed on March 25, 2020).

106. Committee on Obstetric Practice.. ACOG committee opinion. Antenatal corticosteroid therapy for fetal maturation. American College of Obstetricians and Gynecologists. Int J Gynaecol Obstet 2002; 78: 95-7.

107. Wang J, Qi H, Bao L, Li F, Shi Y. A contingency plan for the management of the 2019 novel coronavirus outbreak in neonatal intensive care units. Lancet Child Adolesc Health 2020; 4: 258-9.

108. Mulangu S, Dodd LE, Davey RT Jr, Mbaya OT, Proschan M, Mukadi D et al. A randomized, controlled trial of ebola virus disease therapeutics. N Engl ] Med 2019; 381: 2293-303.

109. Baud D, Giannoni E, Pomar L, Qi X, Nielsen-Saines K, Musso D, et al. COVID-19 in pregnant women - Authors' reply. Lancet Infect Dis. 2020 March 17, doi: 10.1016/S1473-3099(20)30192-4. (Accessed on March 25, 2020).

110. Coronavirus (COVID-19) Infection in Pregnancy Information for healthcare professionals Version 5. 28 March, 2020 Royal College of Obstetricians and gynaecologist. Available from URL: https://www.rcog.org.uk/globalassets/ documents/guidelines/2020-03-28-covid19-pregnancy-guidance.pdf (Accessed on March 29, 2020).

111. Wang G, Zhang Y, Zhao J, Zhang J, Jiang F. Mitigate the effects of home confinement on children during the COVID-19 outbreak. Lancet 2020; 395: 945-7.

112. Sprang G, Silman M. Posttraumatic stress disorder in parents and youth after health-related disasters. Disaster Med Public Health Prep 2013; 7: 105-10.

113. Mitjà O, Clotet B. Use of antiviral drugs to reduce COVID-19 transmission. Lancet Glob Health. 2020 March 19. doi: 10.1016/\$2214-109X(20)30114-5. [Epub ahead of print]. (Accessed on March 26, 2020).

114. Xu X. A multicenter, randomized controlled trial for the efficacy and safety of tocilizumab in the treatment of new coronavirus pneumonia (COVID-19). Chinese Clinical Trial Registry (COVID-19). http://www.chictr.org.cn/ showprojen .aspx?proj=49409 (Accessed on March 15, 2020). 